\title{
Amentoflavone Inhibits Metastatic Potential Through Suppression of ERK/NF-kB Activation in Osteosarcoma U2OS Cells
}

\author{
PO-JUNG PAN ${ }^{1,2,3}$, JAI-JEN TSAI ${ }^{3,4^{*}}$ and YU-CHANG LIU ${ }^{3,5,6^{*}}$ \\ ${ }^{1}$ Department of Physical Medicine and Rehabilitation, ${ }^{3}$ Cancer Medical Care Center, \\ ${ }^{4}$ Division of Gastroenterology, Department of Medicine, and ${ }^{5}$ Department of Radiation Oncology, \\ National Yang-Ming University Hospital, Yilan, Taiwan, R.O.C.; \\ ${ }^{2}$ Faculty of Medicine, School of Medicine, National Yang-Ming University, Taipei, Taiwan, R.O.C.; \\ ${ }^{6}$ Department of Radiological Technology, \\ Central Taiwan University of Science and Technology, Taichung, Taiwan, R.O.C.
}

\begin{abstract}
Aim: The study goal was to investigate effect of amentoflavone on nuclear factor- $\mathrm{k} B(\mathrm{NF}-\mathrm{k} B)$-modulated metastatic mechanism in osteosarcoma U2OS cells. U2OS cells were treated with amentoflavone, $N F-k B$ inhibitor, protein kinase $B(P K B$ or $A K T)$ inhibitor or mitogen-activated protein kinase (MAPK) inhibitor. Change of cell viability, $N F-k B$ activation, expression of metastasis-associated proteins, signal transduction, and cell migration and invasion were evaluated by the 3-(4,5-dimethylthiazol-2-yl)-2,5-diphenyltetrazolium bromide (MTT) assay, $N F-\kappa B$ reporter gene assay, western blotting, and cell migration and invasion assays. The results demonstrated that inhibition of activation of extracellular signal-regulated kinases (ERK) was a key point for suppression of $N F-k B$-modulated metastatic mechanism. Amentoflavone significantly inhibited $N F-k B$ activation, ERK phosphorylation, expression of metastasis-associated proteins, and cell migration and invasion. Our findings indicate that amentoflavone reduces metastatic potential through suppression of ERK and NF-kB activation in osteosarcoma U2OS cells.
\end{abstract}

\footnotetext{
*These Authors contributed equally to this study.

Correspondence to: Yu-Chang Liu, MD, Department of Radiation Oncology, National Yang-Ming University Hospital, No.169, Siaoshe Rd., Yilan City, Yilan County 26058, Taiwan, R.O.C. Tel: +8863932519273181, e-mail: kevinyc.liu@gmail.com and Jai-Jen Tsai, MD, Ph.D., Division of Gastroenterology, Department of Medicine, National Yang-Ming University Hospital No.169, Siaoshe Rd., Yilan City, Yilan County 26058, Taiwan, R.O.C. Tel: +886 3932519273181,e-mail: jjthsai@yahoo.com.tw
}

Key Words: Amentoflavone, nuclear factor-kB, NF-kB, osteosarcoma, metastasis.
Osteosarcoma, the most common type of malignant bone tumor, occurs primarily in children and adolescents, with a second peak of incidence among adults over the age of 50 years (1). The overall survival of patients with osteosarcoma has improved with current treatment methods such as chemotherapy, surgery, and radiotherapy. The 5-year survival rate for patients with localized osteosarcoma is about $65-75 \%$ after treatment. Patients with metastatic osteosarcoma often have unsatisfactory response to chemotherapy or radiotherapy and the resultant 5-year survival rate is only $10-20 \%$ (2). The majority of patient mortality is due to relentless progression of metastasis (3). Therefore, a treatment strategy focusing on combating metastasis may be beneficial in prolonging disease control.

Cancer metastasis is a multistep process by which cancer cells spread from the primary site distantly to form a secondary tumor (4). Metastasis is modulated by metastasisassociated proteins such as vascular endothelial growth factor (VEGF), urinary plasminogen activator (uPA), matrix metalloproteinase-2 (MMP2) and matrix metalloproteinase-9 (MMP9). Angiogenesis, or the formation of new blood vessels, is regulated by expression of VEGF and prerequisite for cancer metastasis (5). When uPA, a serine protease, binds to its receptor (uPAR), it can promote conversion of plasminogen to plasmin, which degrades the extracellular matrix (ECM) and activates MMP2 (72 kDa gelatinase A) and MMP9 (92 kDa gelatinase B). ECM degradation has been implicated in cancer invasion and metastasis $(3,6,7)$.

Nuclear factor-kB $(\mathrm{NF}-\mathrm{kB})$ is an important modulator in tumor progression. Activation of $\mathrm{NF}-\mathrm{kB}$ contributes to cancer metastasis through inducing expression of metastasisassociated proteins (8). Tang et al. found patients whose osteosarcoma had active NF-kB had short median overall survival time as compared to patients whose osteosarcoma had inactive NF-kB (9). Many chemotherapeutic agents, and 
radiation, can induce cell-cycle arrest and apoptosis while activating NF-kB signaling, which may hinder treatment effects $(10,11)$. Inhibitors of NF-kB signaling suppress expression of NF-kB-modulated metastasis-associated proteins and lead to blockage of the metastatic mechanism in osteosarcoma cells, both in vitro and in vivo $(12,13)$. Therefore, development of an inhibitor of NF-kB signaling as an adjuvant agent may be of potential to help patients with osteosarcoma.

Amentoflavone, a flavonoid extracted from Selaginella tamariscina, has been shown to inhibit cell invasion and metastasis via suppression of NF-kB activation in breast cancer and melanoma cells both in vitro and in vivo $(14,15)$. However, whether amentoflavone induces anti-metastatic effect through suppression of NF- $\mathrm{BB}$ activation in osteosarcoma cells is unknown. The goal of the present study was to investigate effect of amentoflavone on NF-kBmodulated metastatic mechanism in osteosarcoma cells. Osteosarcoma U2OS cells were used for this study. The effect of amentoflavone on cell viability, NF-kB activation, expression of metastasis-associated proteins, and cell invasion were evaluated using 3-(4,5-dimethylthiazol-2-yl)-2,5diphenyltetrazolium bromide (MTT) assay, NF-kB reporter gene, western blotting, and matrigel invasion assay. We also verified the role of $\mathrm{NF}_{-\mathrm{KB}}$, protein kinase $\mathrm{B}$ (PKB or AKT), and mitogen-activated protein kinase (MAPK) signaling inhibition in anti-metastatic mechanism.

\section{Materials and Methods}

Chemicals. Amentoflavone and MTT were purchased from SigmaAldrich (St. Louis, MO, USA). McCoy's 5A medium was obtained from Hyclone, GE Healthcare Life Sciences (Logan, UT, USA). Fetal bovine serum (FBS), L-glutamine, and penicillin-streptomycin (PS) were purchased from Gibco/Life Technologies (Carlsbad, CA, USA). $\mathrm{NF}-\mathrm{kB}$ inhibitor 4- $N$-[2-(4-phenoxyphenyl) ethyl] quinazoline-4,6diamine (QNZ), AKT inhibitor LY294002, c-Jun $N$-terminal kinase (JNK) inhibitor SP600125, P38 inhibitor SB203580, and extracellular signal-regulated kinase (ERK) inhibitor PD98059 were bought from Selleckchem (Houston, TX, USA). Primary antibodies of VEGF, MMP-9, and pERK were bought from Merck Millipore (Billerica, MA, USA). Primary antibodies to MMP2 and uPA were purchased from OriGene Technologies (Rockville, MD, USA) and Abbiotec (San Diego, CA, USA), respectively. Primary antibody to $\beta$-actin was bought from Santa Cruz Biotechnology (Santa Cruz, CA, USA). Secondary antibodies were purchased from Jackson ImmunoResearch (West Grove, PA, USA). D-Luciferin and hygromycin B were bought from Caliper (Hopkinton, MA, USA) and Santa Cruz Biotechnology, respectively. Matrigel was purchased from Corning (Tewksbury, MA, USA). jetPEI ${ }^{\mathrm{TM}}$ transfection agent was obtained from Polyplus Transfection (Illkirch, Bas-Rhin, France).

Cell culture. The human osteosarcoma U2OS cells were generously provided by Professor Jing-Gung Chung at Department of Biological Science and Technology, China Medical University, Taichung, Taiwan. Cells were maintained in McCoy's 5A medium supplemented with $10 \%$ FBS, $2 \mathrm{mM} \mathrm{L-glutamine,} \mathrm{and} \mathrm{PS} \mathrm{(100} \mathrm{Units/ml} \mathrm{and}$ $100 \mu \mathrm{g} / \mathrm{ml}$ ) and grown at $37^{\circ} \mathrm{C}$ in a humidified incubator with $5 \%$ $\mathrm{CO}_{2}$ atmosphere (13).

MTT assay. U2OS cells were seeded into 96-well plates with $2 \times 10^{4}$ cells/well and cultured overnight. Cells were then treated with amentoflavone $(50,75$, and $100 \mu \mathrm{M})$, QNZ (EVP4593 or NF-kB inhibitor; 0.3, 0.5, 1, 2, and $3 \mu \mathrm{M}$ ), LY294002 (AKT inhibitor, 10 $\mu \mathrm{M}$ ), SP600125 (JNK inhibitor, $10 \mu \mathrm{M}$ ), PD98059 (ERK inhibitor, $10 \mu \mathrm{M}$ ), and SB203580 (P38 inhibitor, $10 \mu \mathrm{M}$ ), respectively, for 24 and $48 \mathrm{~h}$. After treatments, cell viability was evaluated with MTT assay as described by Chiang et al. (16).

Plasmid transfection. NF-kB-luciferrase2 vector (pNF-kB/luc2) was purchased from Promega (Madison, WI, USA). U2OS cells were transfected with $\mathrm{pNF}-\mathrm{kB} / \mathrm{luc} 2$ using jetPEI ${ }^{\mathrm{TM}}$. Cells $\left(1 \times 10^{6}\right)$ were seeded into $10 \mathrm{~cm}$ dish and cultured overnight. Transfection procedure was as described by Tsai et al. (17).

$N F-k B$ reporter gene assay. U2OS cells transfected with $\mathrm{pNF}-\mathrm{kB} / \mathrm{luc} 2$ were seeded into 96 -well plates with $2 \times 10^{4}$ cells/well and cultured overnight. Cells were then treated with amentoflavone $(50,75$, and $100 \mu \mathrm{M}$ ), QNZ (EVP4593 or NF-kB inhibitor; 0.3, 0.5, 1, 2, and 3 $\mu \mathrm{M}$ ), LY294002 (AKT inhibitor, $10 \mu \mathrm{M}$ ), SP600125 (JNK inhibitor, $10 \mu \mathrm{M}$ ), PD98059 (ERK inhibitor, $10 \mu \mathrm{M}$ ), and SB203580 (P38 inhibitor, $10 \mu \mathrm{M})$, respectively, for 24 and $48 \mathrm{~h}$. D-luciferin solution [500 $\mu \mathrm{M}$ D-luciferin in $100 \mu$ l phosphate-buffered saline (PBS)] was added to each well for 1 min before imaging. The photon signal from cells was acquired for $1 \mathrm{~min}$ using IVIS200 Imaging System (Xenogen, Alameda, CA, USA). After normalizing data with cell viability obtained by MTT assay, relative NF-kB activity was determined as described previously (18).

Western blotting assay. U2OS cells $\left(3 \times 10^{6}\right)$ were seeded into $10 \mathrm{~cm}$ diameter dishes, cultured overnight, and then treated with different concentrations $(75,100 \mu \mathrm{M})$ of amentoflavone, $3 \mu \mathrm{M}$ QNZ, or $10 \mu \mathrm{M}$ PD98059, respectively, for $24 \mathrm{~h}$. Lysis buffer $(50 \mathrm{mM}$ Tris- $\mathrm{HCl} \mathrm{pH}$ 8.0, $120 \mathrm{mM} \mathrm{NaCl}, 0.5 \% \mathrm{NP}-40$, and $1 \mathrm{mM}$ phenylmethanesulfonyl fluoride) was used to extracted total cell protein from each treatment group. Protein levels of uPA, VEGF, MMP2, and MMP9 were evaluated with western blotting assay as described by Ting et al. (19). Protein bands were quantified by using ImageJ software version 1.50 (National Institutes of Health, Bethesda, MD, USA).

Migration assay. Transwell inserts ( $8 \mu \mathrm{m}$ pore size) were obtained from Corning (Tewksbury, MA, USA). A total of $3 \times 10^{6}$ U2OS cells were resuspended with $1 \mathrm{ml}$ serum-free McCoy's 5A medium and treated with $100 \mu \mathrm{M}$ amentoflavone, $3 \mu \mathrm{M}$ QNZ, or $10 \mu \mathrm{M}$ PD98059, respectively. Cell suspension $(100 \mu \mathrm{l})$ was placed in the apical chamber of the transwell insert and cells were incubated for $24 \mathrm{~h}$. McCoy's 5A medium with $10 \%$ serum was added to the basolateral chamber. After treatment, the migrated cells in the permeable membrane of transwells were fixed with mixture of methanol and acetic acid in a ratio $(3: 1)$ for $15 \mathrm{~min}$ and then stained with $0.5 \%$ crystal violet staining solution. Fixed cells were photographed under a light microscope at $\times 100$ and then counted using ImageJ software version 1.50 (National Institutes of Health) (20).

Invasion assay. Transwells ( $8 \mu \mathrm{m}$ pore size) were coated with $50 \mu \mathrm{l}$ matrigel solution $(25 \mu \mathrm{l}$ matrigel in $25 \mu \mathrm{l}$ serum-free McCoy's $5 \mathrm{~A}$ 
A

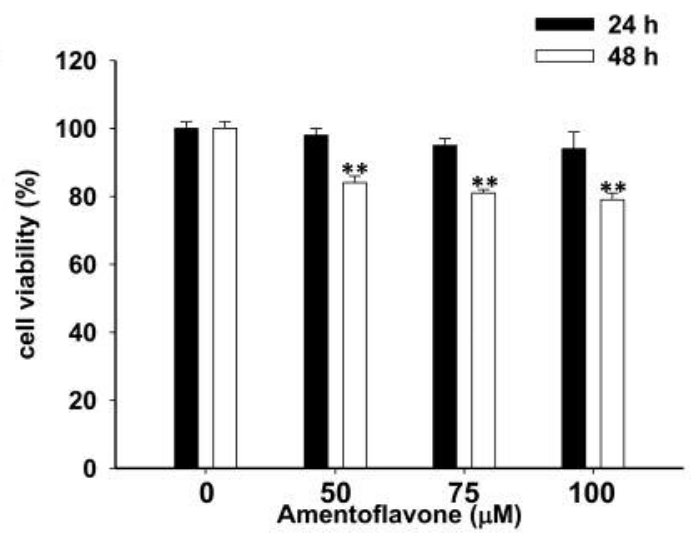

B

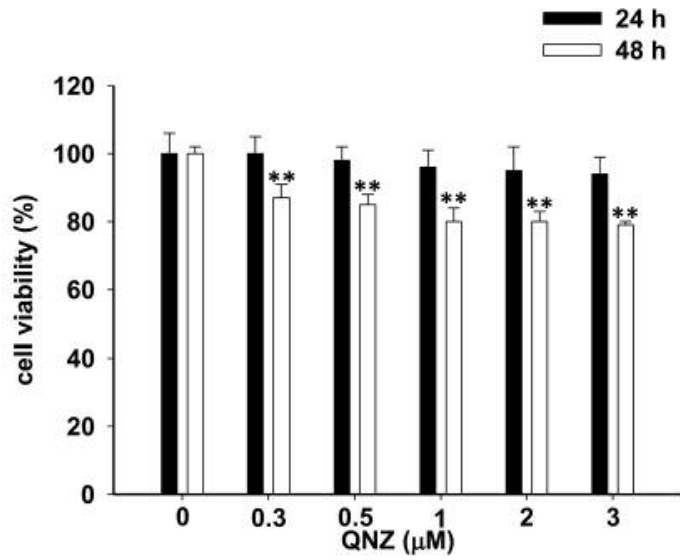

C

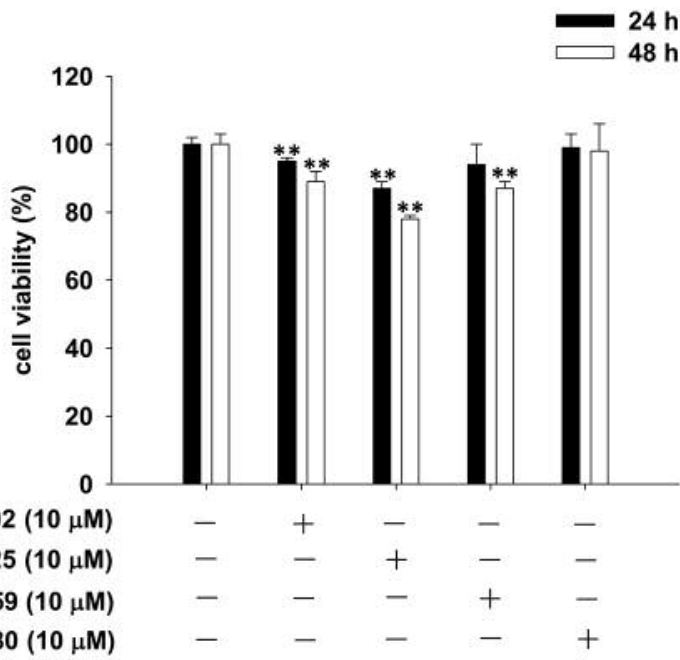

Figure 1. Effects of amentoflavone, nuclear factor-kB $(N F-k B)$ inhibitor, protein kinase $B(P K B$ or $A K T)$ inhibitor, and mitogen-activated protein kinase (MAPK) inhibitors on cell viability in U2OS cells. Cell viability 24 and $48 \mathrm{~h}$ after treatment with amentoflavone (A), QNZ (EVP4593 or $N F-k B$ inhibitor) (B), and LY294002 (AKT inhibitor), SP600125 (c-Jun $N$-terminal kinase inhibitor), PD98059 (extracellular signal-regulated kinases inhibitor), and SB203580 (P38 inhibitor) (C) as evaluated with 3-(4,5-dimethylthiazol-2-yl)-2,5-diphenyltetrazolium bromide assay. **Significantly different at $p<0.01$ compared to the control $(0 \mu M)$.

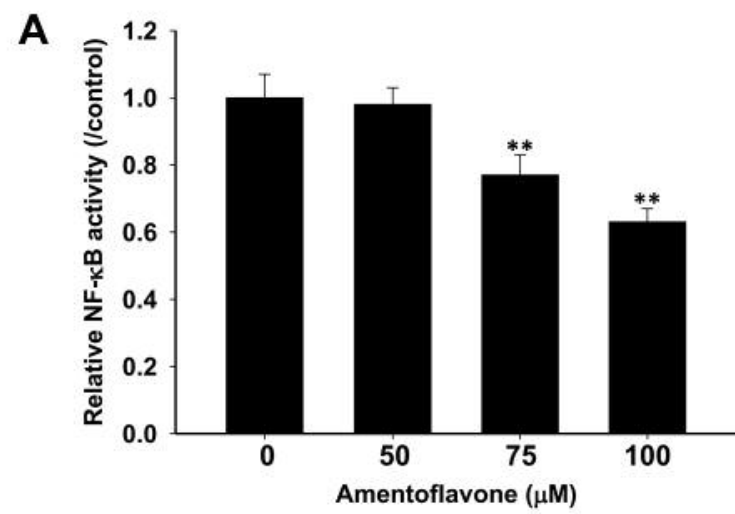

B

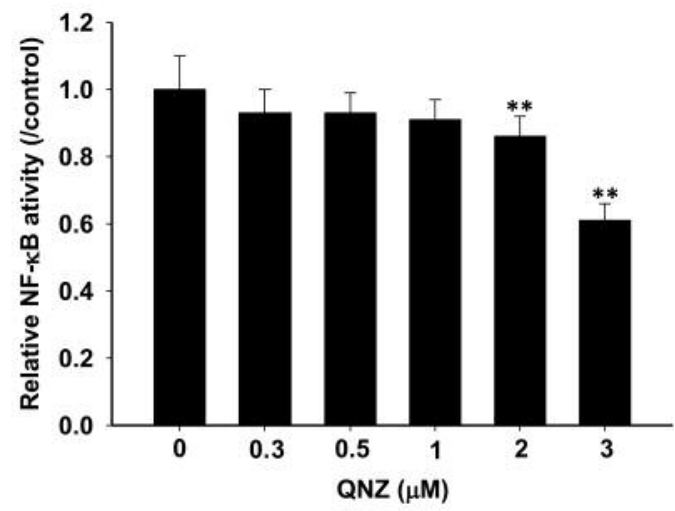

C

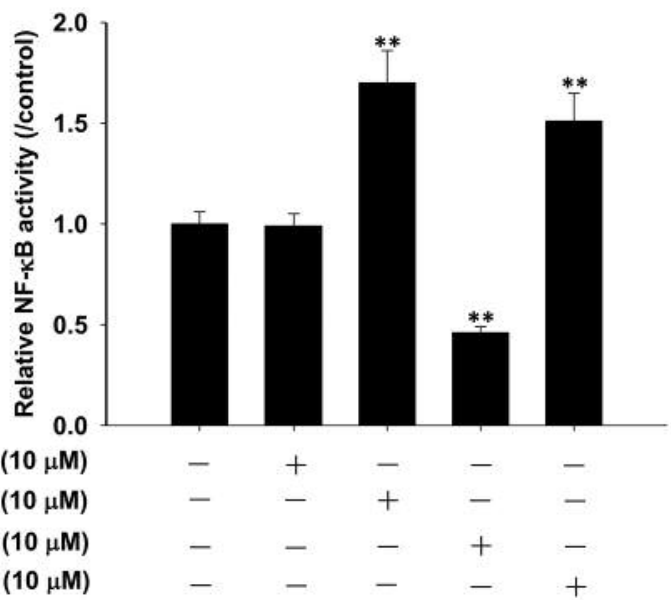

Figure 2. Effects of amentoflavone, nuclear factor- $\mathrm{B} B(N F-\kappa B)$ inhibitor, protein kinase $B(P K B$ or $A K T)$ inhibitor, and mitogen-activated protein kinase (MAPK) inhibitors on NF-kB activation in U2OS cells. Twentyfour and $48 \mathrm{~h}$ after treatment with amentoflavone (A), QNZ (EVP4593 or NF-kB inhibitor) (B), and LY294002 (AKT inhibitor), SP600125 (cJun N-terminal kinase inhibitor), PD98059 (extracellular signalregulated kinases inhibitor), and SB203580 (P38 inhibitor) (C) as evaluated with $N F-k B$ reporter gene assay. ${ }^{*}$ Significantly different at $p<0.01$ compared to the control $(0 \mu M)$. 

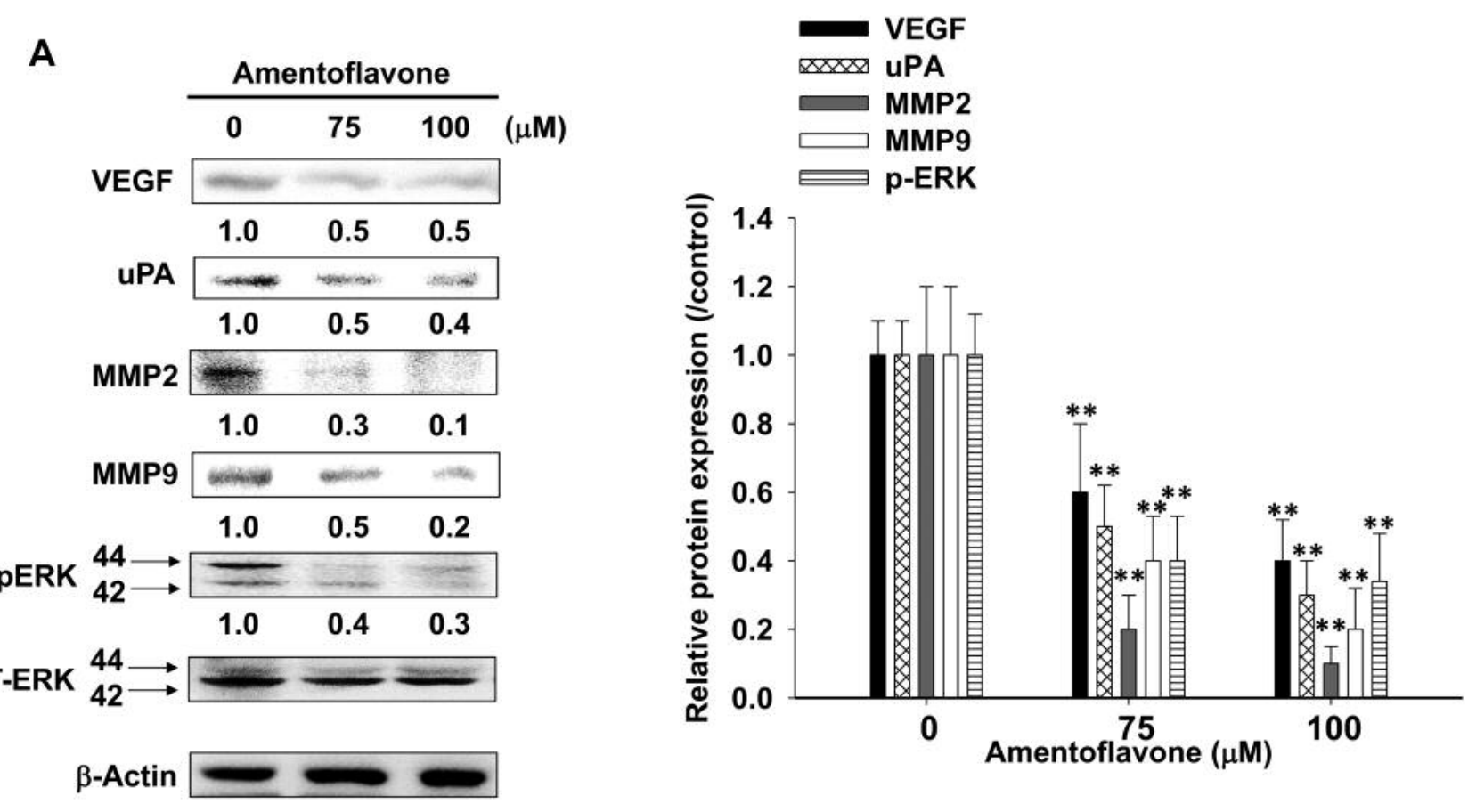

B
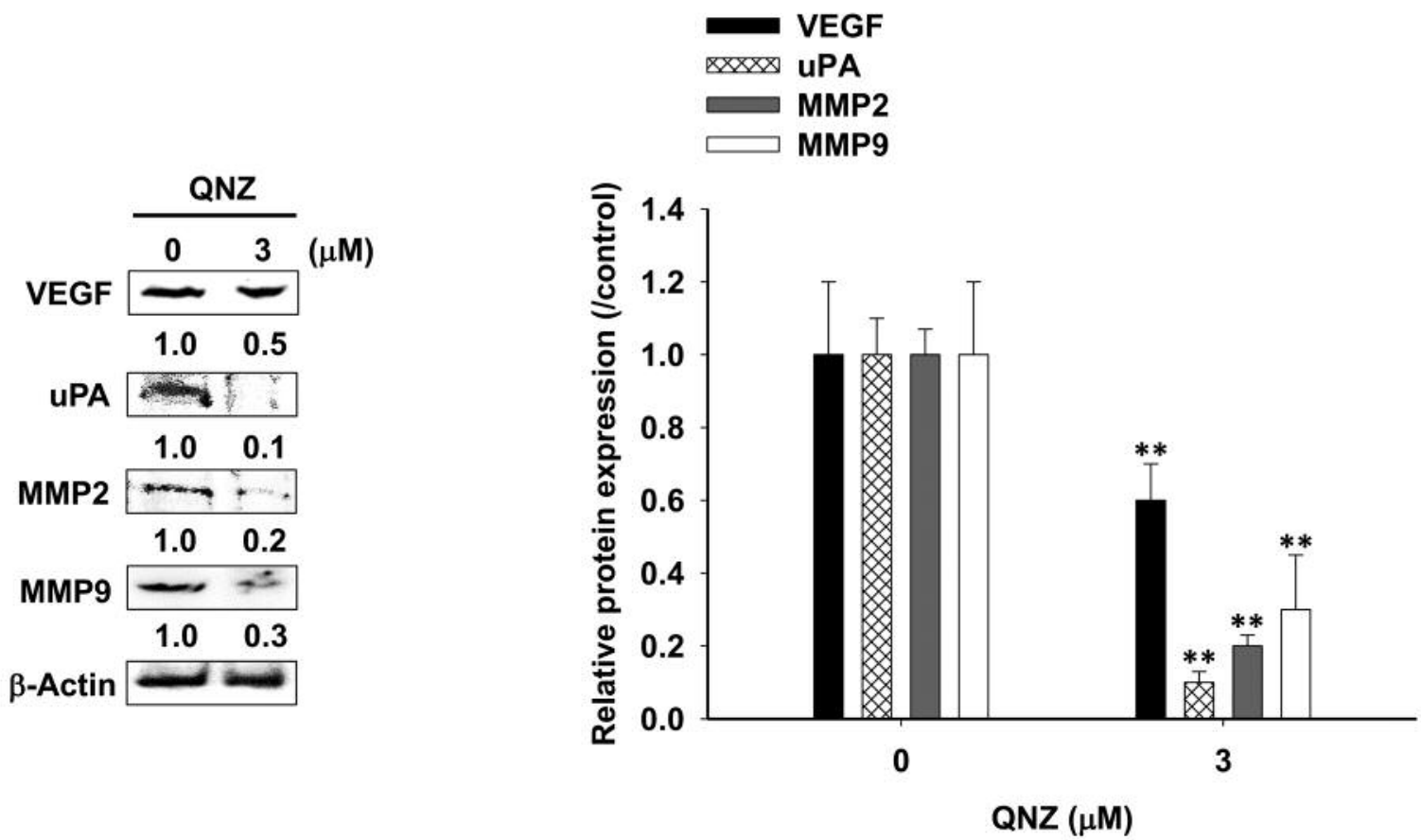

Figure 3. Continued

medium) and incubated overnight at $37^{\circ} \mathrm{C}$ in a humidified incubator. U2OS cells $\left(3 \times 10^{6}\right)$ were resuspended with $1 \mathrm{ml}$ serum-free McCoy's 5A medium and then treated with $100 \mu \mathrm{M}$ amentoflavone, $3 \mu \mathrm{M}$ QNZ, or $10 \mu \mathrm{M}$ PD98059, respectively. Cell suspension $(100 \mu \mathrm{l})$ was placed in the apical chamber of the transwell insert and cells were incubated for $24 \mathrm{~h}$. McCoy's 5A medium with $10 \%$ serum was added to the basolateral chamber. After treatment, a sterile cotton swab was used to remove matrigel on the permeable membrane of the transwell. The invasive cells in the permeable membrane were fixed with a mixture of methanol and acetic acid (3:1) for $15 \mathrm{~min}$ and then stained with 

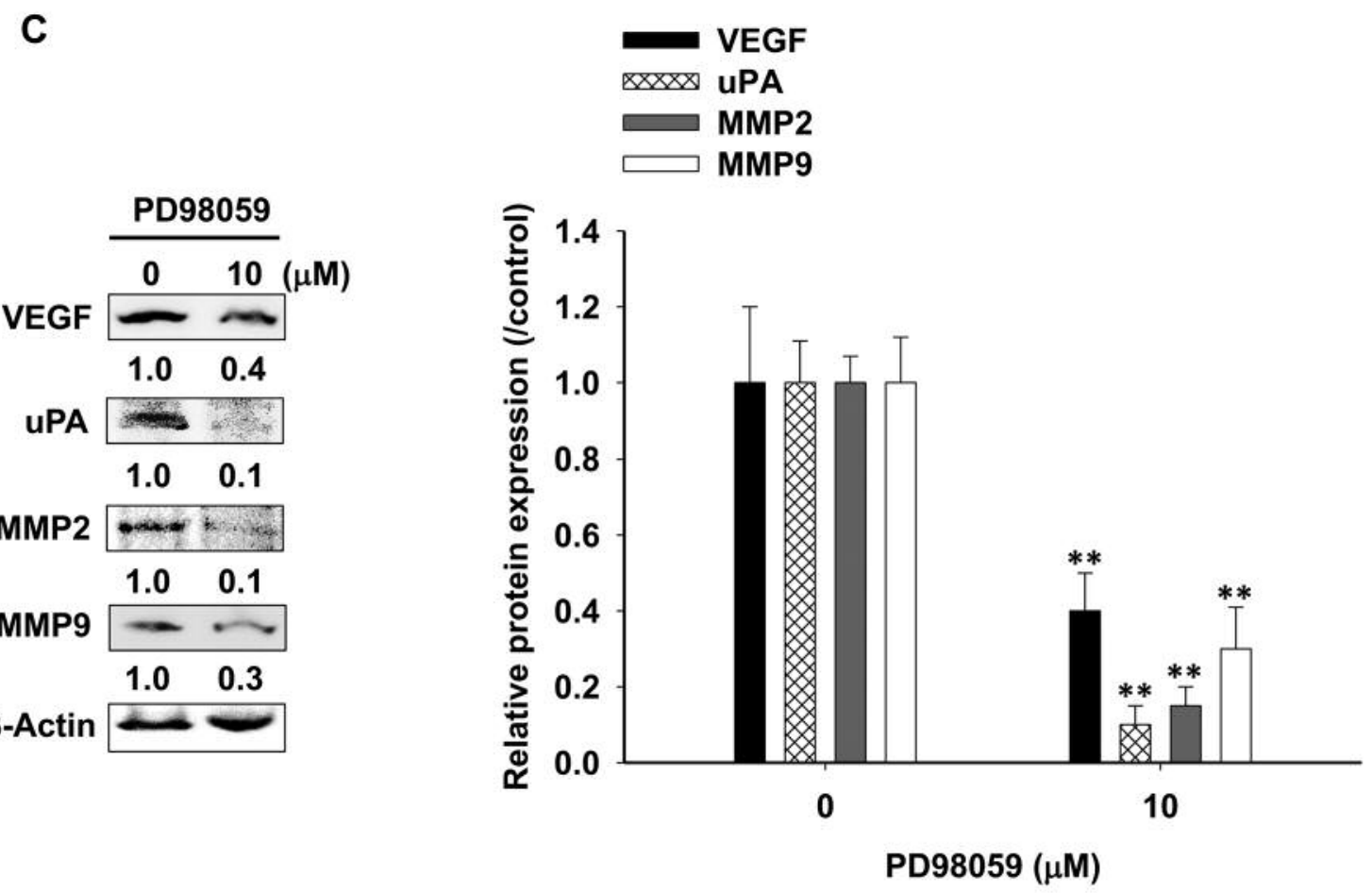

Figure 3. Effects of nuclear factor- $\mathrm{kB}(\mathrm{NF}-\mathrm{k} B)$ inhibitor, extracellular signal-regulated kinases $(E R K)$ inhibitor, and amentoflavone on expression of metastasis-associated proteins in U2OS cells. Cells were treated with different concentrations of amentoflavone (A), QNZ (EVP4593 or NF-KB inhibitor) (B), and PD98059 (ERK inhibitor) (C) for 24 h. Proteins expression of vascular endothelial growth factor (VEGF), urinary plasminogen activator (uPA), matrix metalloproteinase-2 (MMP2), MMP9, and phosphorylated ERK $24 \mathrm{~h}$ after treatment were analyzed with western blotting

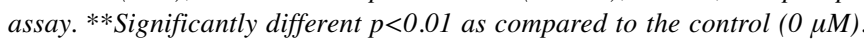

$0.5 \%$ crystal violet staining solution. Fixed cells were photographed under a light microscope at $\times 100$ and then counted using Image $J$ software version 1.50 (National Institutes of Health) (21).

Statistical analysis. Student's $t$-test was used to test the significance of differences in mean values between different groups. $p$-Values of 0.05 or less were considered statistically significant. Each experiment was carried out three times.

\section{Results}

Effect of amentoflavone, $N F-k B$ inhibitor, AKT inhibitor, and $M A P K$ inhibitor on viability of U2OS cells. Figure $1 \mathrm{~A}$ indicates that amentoflavone induced cytotoxicity in a timedependent manner. Cell viability remained relatively unchanged when cells were treated with different concentrations $(50,75$, and $100 \mu \mathrm{M})$ of amentoflavone for 24 h. After treatment with amentoflavone at the same concentration for $48 \mathrm{~h}$, cell viability was significantly reduced as compared to the control. Figure 1B indicates that QNZ inhibited cell growth in a time-dependent manner. Cell viability remained unchanged when cells were treated with different concentrations $(0.3,0.5,1,2$, and $3 \mu \mathrm{M})$ of QNZ for $24 \mathrm{~h}$. After treatment with QNZ for $48 \mathrm{~h}$, cell viability was significantly decreased as compared to the control. Figure 1C showed that cell viability significantly decreased after treatment with LY294002 or SP600125 for $24 \mathrm{~h}$ as compared to the control. In addition, after treatment with $10 \mu \mathrm{M}$ LY294002, SP600125, PD98059, or SB203580 for 48 h, only SB203580 did not significantly influence cell viability.

Amentoflavone, $N F-k B$ inhibitor, and ERK inhibitor reduce $N F-k B$ activation in $U 2 O S$ cells. Figure $2 \mathrm{~A}$ shows that amentoflavone treatment at 75 and $100 \mu \mathrm{M}$ significantly inhibited NF-kB activation by $23-37 \%$ as compared to the control. Figure $2 \mathrm{~B}$ shows QNZ treatment at 2 and $3 \mu \mathrm{M}$ significantly reduced NF-kB activation by $14-39 \%$ as compared to the control. Figure $2 \mathrm{C}$ indicates that after treatment with $10 \mu \mathrm{M}$ AKT, JNK, ERK, or P38 inhibitor for 24 h, only ERK inhibitor (PD98059) significantly inhibited $\mathrm{NF}-\mathrm{kB}$ activation, by $50 \%$ as compared to the control, and can be referred to as a NF-kB signal inhibitor.

Amentoflavone, $\mathrm{NF}-\mathrm{kB}$ inhibitor, and ERK inhibitor suppress expression of metastasis-associated proteins in U2OS cells. QNZ and PD98059 were used to verify the effect of NF-kB and ERK inactivation on expression of metastasis-associated 

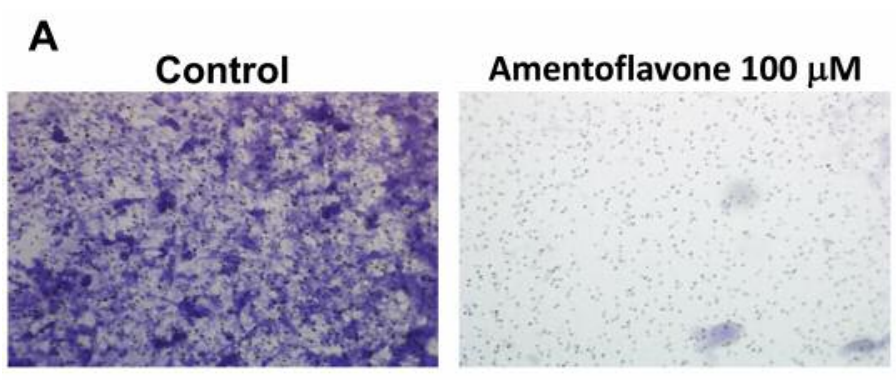

PD98059 $10 \mu \mathrm{M}$
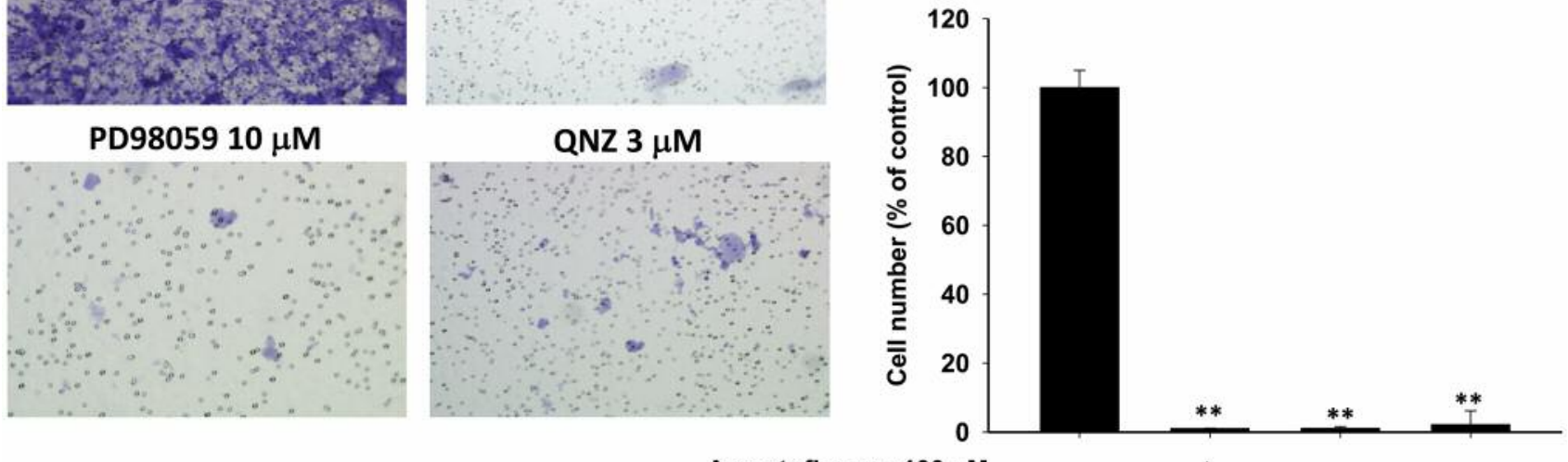

Amentoflavone $100 \mu \mathrm{M}$

PD98059 $10 \mu \mathrm{M}$

QNZ $3 \mu \mathrm{M}$

B

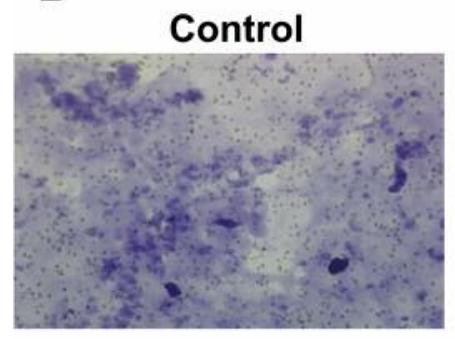

PD98059 $10 \mu \mathrm{M}$
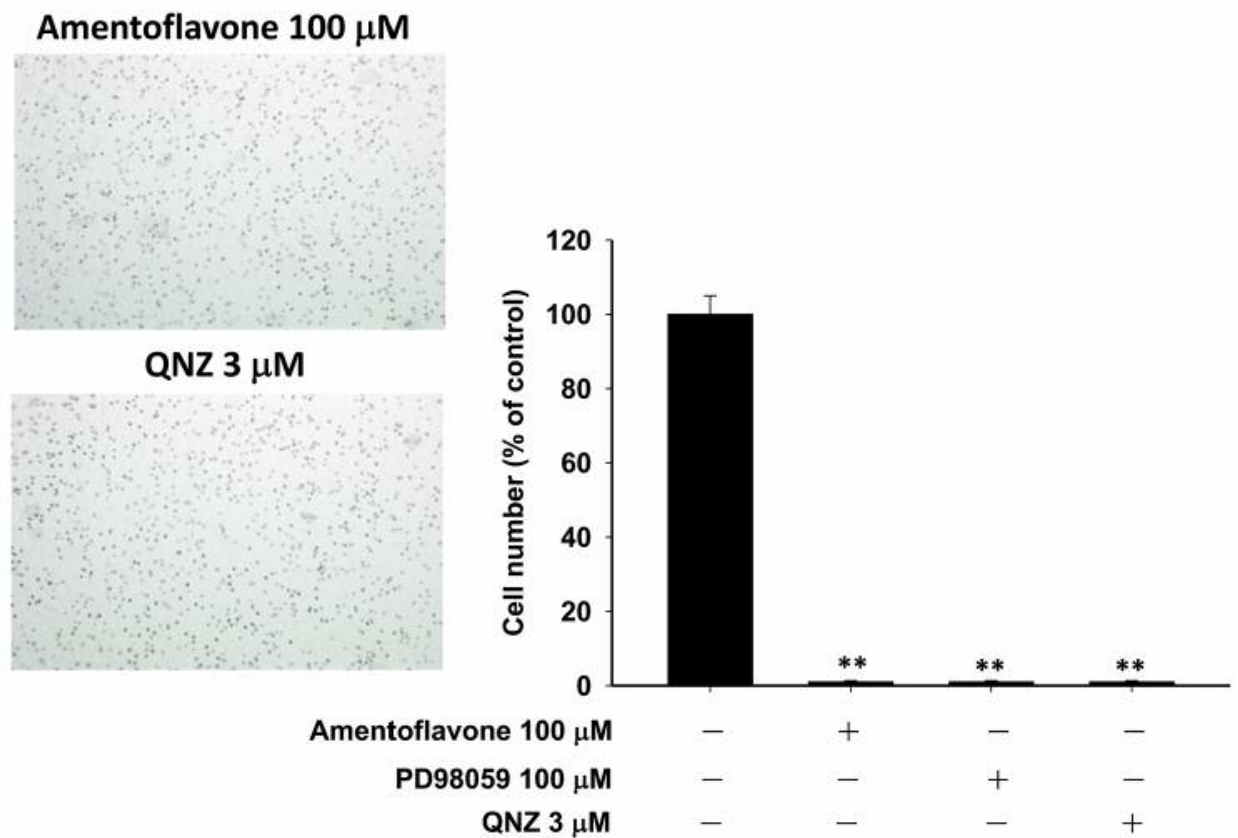

Figure 4. Effect of treatment for $24 \mathrm{~h}$ with amentoflavone, QNZ (EVP4593 or nuclear factor-kB inhibitor), and PD98059 (extracellular signalregulated kinases inhibitor) on cell migration and invasion by U2OS cells. A: Numbers of migrated cells were evaluated with migration assay. B: Numbers of invading cells were evaluated with matrigel invasion assay. **Significantly different at $p<0.01$ as compared to the control $(0 \mu M)$.

proteins in U2OS cells. We found amentoflavone treatment (75 and $100 \mu \mathrm{M}$ ) significantly reduced expression of metastasis-associated proteins VEGF, uPA, MMP2, and MMP9 and ERK phosphorylation by $60-90 \%$ as compared to the control (Figure 3A). Figure 3B and $\mathrm{C}$ show that treatment with $3 \mu \mathrm{M}$ QNZ or $10 \mu \mathrm{M}$ PD98059 significantly inhibited expression of VEGF, uPA, MMP2, and MMP9 by 40-90\% as compared to the control. 
Amentoflavone, $N F-k B$ inhibitor, and ERK inhibitor prevent cell migration and invasion by U2OS cells. Amentoflavone, PD98059, and QNZ all significantly prevented cell migration and invasion of U20S cells by $95-98 \%$ (Figure 4A and B) compared to the control.

\section{Discussion}

Expression of metastasis-associated proteins, cell invasion and metastasis are linked to NF- $\mathrm{kB}$ activation in osteosarcoma. Liao et al. used shRNA to knockdown NF-kB in order to abolish cell invasion and metastasis in osteosarcoma both in vitro and in vivo (12). In this study, we also used QNZ (NF-kB inhibitor) to suppress NF-kB activation leading to inhibition of expression of metastasisassociated proteins, cell migration, and cell invasion in U2OS cells (Figure 2B, 3B and 4). AKT and MAPK signaling have been proposed to regulate NF-KB activation and metastasis in osteosarcoma cells. Some anticancer agents diminish NF-kB-modulated mechanism of metastasis by inhibiting AKT and MAPK signaling in osteosarcoma cells (22-24). Zhu et al. found inhibition of AKT/NF-kB activation reduced cell invasion and migration by osteosarcoma cells in vitro (22). We used AKT and MAPK inhibitors to investigate the role of AKT and MAPK signaling in NF-kB-modulated mechanism of metastasis in U2OS cells. We found only the ERK inhibitor PD98059 reduced NF-kB activation. We also found PD98059 inhibited expression of metastasis-associated proteins, cell invasion and metastasis (Figures 3C and 4). Based on the above data we suggest blockage of ERK/NF-kB activation leads to inhibition of metastasis-associated protein expression, cell migration, and cell invasion in U2OS cells. Li et al. also found down-regulation of ERK/NF-kB pathway resulted in inhibition of invasive properties in U2OS cells (24).

ERK (MAPK) plays a major role in the hallmarks of cancer, which include evasion of apoptosis, tumor growth, angiogenesis, and metastasis (25). Na et al. demonstrated overexpression of phosphorylated ERK was associated with poor prognosis in patients with osteosarcoma (26). Inhibition of ERK phosphorylation impedes cell invasion and metastatic potential in osteosarcoma (25). Sorafenib (Nexavar), an oral multikinase inhibitor of platelet-derived growth factor (PDGF), VEGF receptor, and rapidly accelerated fibrosarcoma kinases, is indicated for use in patients with recurrent high-grade osteosarcoma based on a phase II clinical trial with a $14 \%$ overall tumor response rate, $49 \%$ disease control rate, and expected 4-month progression-free survival $(27,28)$. Pignochino et al. showed that sorafenib reduced protein expression of VEGF, MMP2, and pERK in different types of osteosarcoma cells (27). Our results show amentoflavone inhibited NF-kB activation, ERK phosphorylation, expression of metastasis-associated

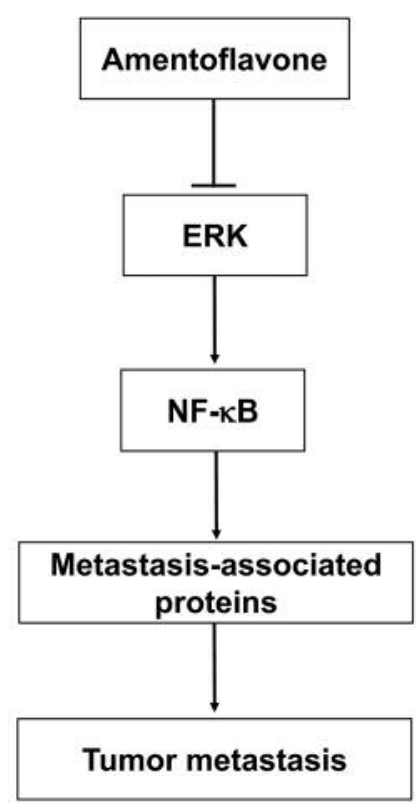

Figure 5. The suggested mechanism of action for amentoflavone reduction of metastatic potential through suppression of nuclear factor-kB extracellular signal-regulated kinases (ERK)/nuclear factor- $k B(N F-\kappa B)$ activation in U2OS osteosarcoma cells.

proteins, cell migration, and cell invasion. In our previous study, amentoflavone induced anti-metastatic effect through suppression of NF-kB activation (14). Therefore, we suggest amentoflavone reduces metastatic potential through suppression of ERK/NF-kB signaling pathway (Figure 5) in osteosarcoma U2OS cells.

\section{Conclusion}

This study indicated amentoflavone inhibited expression of metastasis-associated proteins, cell migration, and cell invasion through suppression of ERK/NF-KB signaling pathway in osteosarcoma U2OS cells. We propose the potential application of amentoflavone for patients with osteosarcoma as adjuvant treatment.

\section{Conflicts of Interest}

The Authors declare no conflict of interest in regard to this study.

\section{Acknowledgements}

This work was supported by a grant to PJ Pan (RD2017-017) from the National Yang-Ming University Hospital, Yilan, Taiwan. The Authors acknowledge the technical services provided by Clinical Medicine Research Laboratory of National Yang-Ming University Hospital, Yilan, Taiwan. 


\section{References}

1 Kansara M, Teng MW, Smyth MJ and Thomas DM: Translational biology of osteosarcoma. Nat Rev Cancer 14: 722-735, 2014.

2 Endo-Munoz L, Cai N, Cumming A, Macklin R, Merida de Long L, Topkas E, Mukhopadhyay P, Hill M and Saunders NA: Progression of osteosarcoma from a non-metastatic to a metastatic phenotype is causally associated with activation of an autocrine and paracrine uPA axis. PLoS One 10: e0133592, 2015.

3 Huang YM, Hou CH, Hou SM and Yang RS: The metastasectomy and timing of pulmonary metastases on the outcome of osteosarcoma patients. Clin Med Oncol 3: 99-105, 2009.

4 Tsai JH and Yang J: Epithelial-mesenchymal plasticity in carcinoma metastasis. Genes Dev 27: 2192-2206, 2013.

5 Kaya M, Wada T, Akatsuka T, Kawaguchi S, Nagoya S, Shindoh M, Higashino F, Mezawa F, Okada F and Ishii S: Vascular endothelial growth factor expression in untreated osteosarcoma is predictive of pulmonary metastasis and poor prognosis. Clin Cancer Res 6: 572-577, 2000.

6 Wen X, Liu H, Yu K and Liu Y: Matrix metalloproteinase 2 expression and survival of patients with osteosarcoma: a metaanalysis. Tumour Biol 35: 845-848, 2014.

7 Li H, Zhang K, Liu LH, Ouyang Y, Bu J, Guo HB and Xiao T: A systematic review of matrix metalloproteinase 9 as a biomarker of survival in patients with osteosarcoma. Tumour Biol 35: 54875491, 2014.

8 Pacifico F and Leonardi A: NF- $\mathrm{kB}$ in solid tumors. Biochem Pharmacol 72: 1142-52, 2006.

9 Tang QL, Xie XB, Wang J, Chen Q, Han AJ, Zou CY, Yin JQ, Liu DW, Liang Y, Zhao ZQ, Yong BC, Zhang RH, Feng QS, Deng WG, Zhu XF, Zhou BP, Zeng YX, Shen JN and Kang T: Glycogen synthase kinase-3 $\beta, N F-\mathrm{kB}$ signaling and tumorigenesis of human osteosarcoma. J Natl Cancer Inst 104: 749-763, 2012.

10 Godwin P, Baird AM, Heavey S, Barr MP, O'Byrne KJ and Gately $\mathrm{K}$ : Targeting nuclear factor-kappa $\mathrm{B}$ to overcome resistance to chemotherapy. Front Oncol 3: 120, 2013.

11 Magné N, Toillon RA, Bottero V, Didelot C, Houtte PV, Gérard JP and Peyron JF: NF-kB modulation and ionizing radiation: mechanisms and future directions for cancer treatment. Cancer Lett 231: 158-168, 2006.

12 Liao D, Zhong L, Duan T, Zhang RH1, Wang X, Wang G, Hu K, Lv $\mathrm{X}$ and Kang T: Aspirin suppresses the growth and metastasis of osteosarcoma through the NF-kB pathway. Clin Cancer Res 21: 5349-5359, 2015.

13 Liao CL, Lai KC, Huang AC, Yang JS, Lin JJ, Wu SH, Gibson Wood W, Lin JG and Chung JG: Gallic acid inhibits migration and invasion in human osteosarcoma U-2 OS cells through suppressing the matrix metalloproteinase-2/-9, protein kinase B (PKB) and PKC signaling pathways. Food Chem Toxicol 50: 1734-1740, 2012.

14 Chen JH, Chen WL and Liu YC: Amentoflavone induces antiangiogenic and anti-metastatic effects through suppression of NF$\mathrm{KB}$ activation in MCF-7 cells. Anticancer Res 35: 6685-6693, 2015.

15 Guruvayoorappan C and Kuttan G: Effect of amentoflavone on the inhibition of pulmonary metastasis induced by B16F-10 melanoma cells in C57BL/6 mice. Integr Cancer Ther 6: 185-197, 2007.

16 Chiang IT, Chen WT, Tseng CW, Chen YC, Kuo YC, Chen BJ, Weng MC, Lin HJ and Wang WS: Hyperforin Inhibits cell growth by inducing intrinsic and extrinsic apoptotic pathways in hepatocellular carcinoma cells. Anticancer Res 37: 161-167, 2017.
17 Tsai JJ, Pan PJ and Hsu FT: Regorafenib induces extrinsic and intrinsic apoptosis through inhibition of ERK/NF-kB activation in hepatocellular carcinoma cells. Oncol Rep 37: 1036-1044, 2017.

18 Hsu FT, Liu YC, Chiang IT, Liu RS, Wang HE, Lin WJ and Hwang JJ: Sorafenib increases efficacy of vorinostat against human hepatocellular carcinoma through transduction inhibition of vorinostat-induced ERK/NF-kB signaling. Int J Oncol 45: 177$188,2014$.

19 Ting CY, Wang HE, Yu CC, Liu HC, Liu YC and Chiang IT: Curcumin triggers DNA damage and inhibits expression of DNA repair proteins in human lung cancer cells. Anticancer Res 35: 3867-3873, 2015.

20 Lai KC, Huang AC, Hsu, SC, Kuo CL, Yang JS, Wu SH and Chung JG: Benzyl isothiocyanate (BITC) inhibits migration and invasion of human colon cancer HT29 cells by inhibiting matrix metalloproteinase-2/-9 and urokinase plasminogen (uPA) through PKC and MAPK signaling pathway. J Agric Food Chem 58: 2935-2942, 2010.

21 Ma CY, Ji WT, Chueh FS, Yang JS, Chen PY, Yu CC and Chung JG: Butein inhibits the migration and invasion of SK-HEP-1 human hepatocarcinoma cells through suppressing the ERK, JNK, p38 and uPA signaling multiple pathways. J Agric Food Chem 59: 9032-9038, 2011.

22 Zhu LB, Jiang J, Zhu XP, Wang TF, Chen XY, Luo QF, Shu Y, Liu ZL and Huang SH: Knockdown of Aurora-B inhibits osteosarcoma cell invasion and migration via modulating PI3K/AKT/NF-KB signaling pathway. Int J Clin Exp Pathol 7: 3984-3991, 2014.

23 Cheng HL, Hsieh MJ, Yang JS, Lin CW, Lue KH, Lu KH and Yang SF: Nobiletin inhibits human osteosarcoma cells metastasis by blocking ERK and JNK-mediated MMP expression. Oncotarget 7: 35208-35223, 2016.

24 Li Y, Zhang ZN, Zhao HM, Tong ZC, Yang J, Wang H and Liang XJ: Matrine inhibits the invasive properties of human osteosarcoma cells by down-regulating the ERK-NF-kB pathway. Anticancer Drugs 25: 1035-1043, 2014.

25 Chandhanayingyong C, Kim Y, Staples JR, Hahn C and Lee FY: MAPK/ERK signaling in osteosarcomas, Ewing sarcomas and chondrosarcomas: Therapeutic Implications and future directions. Sarcoma 2012: 404810, 2012.

$26 \mathrm{Na} \mathrm{KY,} \mathrm{Kim} \mathrm{YW} \mathrm{and} \mathrm{Park} \mathrm{YK:} \mathrm{Mitogen-activated} \mathrm{protein} \mathrm{kinase}$ pathway in osteosarcoma. Pathology 44: 540-546, 2012.

27 Pignochino Y, Grignani G, Cavalloni G, Motta M, Tapparo M, Bruno S, Bottos A, Gammaitoni L, Migliardi G, Camussi G, Alberghini M, Torchio B, Ferrari S, Bussolino F, Fagioli F, Picci $\mathrm{P}$ and Aglietta M: Sorafenib blocks tumour growth, angiogenesis and metastatic potential in preclinical models of osteosarcoma through a mechanism potentially involving the inhibition of ERK1/2, MCL-1 and ezrin pathways. Mol Cancer 8: 118, 2009.

28 Grignani G, Palmerini E, Dileo P, Asaftei SD, D’Ambrosio L, Pignochino Y, Mercuri M, Picci P, Fagioli F, Casali PG, Ferrari S and Aglietta M: A phase II trial of sorafenib in relapsed and unresectable high-grade osteosarcoma after failure of standard multimodal therapy: an Italian Sarcoma Group study. Ann Oncol 23: 508-516, 2012. 